\title{
UJI AKTIVITAS EKSTRAK ETANOL KULIT PISANG MAS (Musa Acuminata (AA Group)) TERHADAP PENURUNAN KADAR GLUKOSA DARAH MENCIT (Mus musculus) YANG DIINDUKSI ALOKSAN
}

\author{
Kadek Evi D.P. Dewi, Abdul Wahid Jamaluddin, Fedri Rell \\ Program Studi Kedokteran Hewan, Fakultas Kedokteran, Universitas Hasanuddin. \\ Email: abdulwahidjamaluddin@unhas.ac.id; kadekevidian@gmail.com
}

\begin{abstract}
Diabetes mellitus (DM) is a metabolic diseases caused by impaired insulin secretion. The prevalence of DM in pets increased from 2006 until 2015. Therapy by using insulin feared can be worse for patient, so yhat alternative medicine is needed like banana peel. The aims of this study isto determine the effect ofethanol extract of Mas banana peel (Musa acuminata (AA Group)) to decrease level of glucose in mice's blood (Mus musculus) were induced by alloxan. This research was conducted in June 2017 at Biopharmaceutical Laboratory Faculty of Pharmacy, Hasanuddin University. This study uses 24 male mice which divided into 6 groups where the normal control (standard diet), negative control (Na.Cmc 1\%), positive control (Metformin 140mg/KgBB) and treatment group by ethanol extract of Mas banana peel $1 \%, 5 \%$, and $25 \%$. The treatment was given for 10 days. Data were analyzed using one way Anova. The result of this study showed that ethanol extract in banana peel decrease the level of blood glucose which the decrease percentage are $43,15 \%, 54,61 \%, 74,28 \%$. The summary of this research is the treatment by using variant concentration of ethanol extract of Mas banana peelfor 10 days give the significant effect for decreasing the level of blood glucose $(p<0,05)$ and the activity of ethanol extract of Mas Banana Peel 25\% are not give the significant effect with metformin dose 140mg/KgBB ( $p>0,05)$.
\end{abstract}

Key Words: Alloxan, blood glucose, hyperglychemia, mas banana peel, mice.

\section{PENDAHULUAN}

Glukosa darah adalah gula
yang terdapat dalam darah yang
terbentuk dari karbohidrat dalam
makanan dan disimpan sebagai glikogen di hati dan otot rangka. Glukosa adalah karbohidrat terpenting bagi tubuh karena glukosa bertindak sebagai bahan bakar metabolik utama. $^{1}$
Salah satu abnormalitas kadar glukosa darah dimana keadaan dimana kadar glukosa darah meningkat tajam yang disebut hiperglikemia. Hiperglikemia merupakan salah satu penanda terjadinya kelainan metabolisme karbohidrat, lipid, dan protein. Hiperglikemia mengakibatkan peningkatan radikal bebas di dalam sel 
Uji aktivitas ekstrak etanol kulit pisang mas (Musa Acuminata (AA Group)) terhadap penurunan kadar glukosa darah mencit (Mus musculus) yang diinduksi aloksan

dan dalam jumlah berlebihan dapat bersifat toksik yang mendorong terjadinya stress oksidatif. Diabetes mellitus adalah sekelompok penyakit metabolik berupa hiperglikemia yang diakibatkan oleh gangguan sekresi insulin, kerja insulin, atau keduanya. ${ }^{2}$

Kejadian hiperglikemia pada hewan kesayangan banyak terjadi pada anjing dan kucing apabila kadar glukosa darahnya melebihi kadar normal. Kadar glukosa darah normal pada kucing berkisar 55-160 $\mathrm{mg} / \mathrm{dl}$.Sedangkan pada anjing berkisar 80-120 mg/dL. ${ }^{3} \quad$ Pada anjing predisposisi diabetes terjadi pada 414 tahun dan sebagian besar didiagnosis pada usia 7-10 tahun. Sedangkan, pada kucing, berusia lebih dari 6 tahun. ${ }^{4}$

Daun dan buah yang ada disekitar kita ternyata memiliki potensi aktivitas sebagai obat contohnya daun jambu biji yang memiliki sifat antibakteri $^{5}$ dan kulit pisang yang memiliki potensi sebagai antihiperglikemik. Kulit pisang mengandung antioksidan yang tinggi dibandingkan dengan dagingnya. Senyawa antioksidan yang terdapat pada kulit pisang yaitu katekin, gallokatekin, dan epikatekin yang merupakan golongan senyawa flavonoid. ${ }^{6}$ Senyawa lain yang terkandung dalam kulit pisang matang yaitu anthosianin delphinidin, cyaniding, katekolamin, dan saponin. Kandungan antioksidan yang tinggi pada kulit pisang ini dianggap mampu memberikan efek antihiperglikemik dalam tubuh. ${ }^{7}$ Penggunaan ekstrak etanol kulit pisang mampu menghambat proses peroksida yang merupakan reaksioksidasi berefek pada resistensi insulin antara reseptor dan produksi insulin dipankreas. Kandungan antioksidan yang tinggi pada kulit pisang ini juga dipercaya mampu mengatasi keadaan stress oksidatif pada kasus hiperglikemia. ${ }^{8}$

\section{METODE KERJA}

\section{Alat dan Bahan}

Bahan yang digunakan dalam penelitian meliputi kulit Pisang Mas, Aloksan Monohydrate, aquadest, etanol $70 \%$, $\mathrm{Na}$ CMC 1\%, air minum, metformin $500 \mathrm{mg}$, magnesium, asam klorida, $\mathrm{FeCl}_{3}$ dan stripglukometer. Alat yang digunakan dalam penelitian ini adalah neraca analitik, mesin herbs drayer, ultrasonik bath "Branson 2210" $50 \mathrm{kHz}$, glukometer, sonde mencit, alat tulis, gelas ukur $100 \mathrm{~mL}$, kain saring, rotary vacuum evaporator "Butchi", spoit, masker, handskun, botol kaca, toples kaca, sendok, beaker glass, cawan porselen, tabung reaksi, rak tabung, kompor dan kamera. 
Uji aktivitas ekstrak etanol kulit pisang mas (Musa Acuminata (AA Group)) terhadap penurunan kadar glukosa darah mencit (Mus musculus) yang diinduksi aloksan

Prosedur Penelitian

Pembuatan Ekstrak Etanol Kulit Pisang Mas Metode Sonikasi

Proses ekstraksi kulit Pisang Mas dilakukan secara bertahap mulai dari pembelian Pisang Mas di Pasar Daya Kota Makassar. Selanjutnya dilakukan disortasi basah atau pencucian kulit pisang di air mengalir untuk menghilangkan kotoran yang melekat pada kulit pisang lalu ditiriskn hingga kering melalui proses penganginan alami. Selanjutnya dilakukan pemotongan kulit pisang menjadi potongan yang lebih kecil dengan ukuran sekitar $3 \times 4 \mathrm{~cm}$ dan dilanjutkan dengan melakukan pengurangan kadar air pada kulit pisang dengan metode pengeringan menggunakan Herbs drayer. Setelah kulit pisang kering dilakukan disortasi kering, kulit pisang diserbukkan dengan menggunakan blender kering tanpa air hingga diperoleh simplisia kulit pisang. Simplisia kulit pisang kemudian dimasukkan ke dalam wadah (toples kaca) dan ditambah dengan pelarut etanol $70 \%$ dengan rasio biomassa sel : pelarut adalah 1:2 (b/v). Campuran biomassa dan pelarut tersebut kemudian diekstraksi dengan metode sonikasi menggunakan gelombang ultrasonik pada frekuensi $50 \mathrm{kHz}$ selama 30 menit. Hasil ekstraksi disaring dengan kain saring sehingga diperoleh ekstrak cair dengan pelarut lalu dilakukan penguapan dengan menggunakan rotary vacuum evaporator suhu $40^{\circ} \mathrm{C}$, kecepatan 60 rpm, dan tekanan 200mBar sampai tidak ada lagi pelarut yang menetes hingga diperoleh ekstrak berupa ekstrak kental. ${ }^{9}$

\section{Uji Kandungan Fitokimia Kulit} Pisang Mas

Pengujian fitokimia dilakukan untuk mengetahui kandungan senyawa aktif yang terdapat pada ekstrak kulit Pisang Mas secara kualitatif. Pengujian fitokimia yang dilakukan untuk kandungan flavonoid, tannin, saponin. ${ }^{10}$

\section{Perlakuan Terhadap Hewan Uji}

Sebanyak 24 mencit dipilih sesuai kriteria sampel lalu di kelompokkan menjadi 6 kelompok. Mencit diaklimatisasi selama 7 hari. Pakan mencit yang diberikan yakni pakan standar AD-1 sebanyak $4 \mathrm{~g} /$ hari dan air minum sebanyak $7 \mathrm{ml} /$ hari. $^{11}$ Sebelum pemeriksaan kadar glukosa darah, mencit dipuasakan selama 16 jam terlebih dahulu.12 Pemeriksaan kadar glukosa awal (GDP0) terhitung pada hari ke 0 . Kemudian semua kelompok kecuali kelompok tanpa perlakuan disuntikkan aloksan rute subkutan dengan dosis $210 \mathrm{mg} / \mathrm{kgBB}$. 
Uji aktivitas ekstrak etanol kulit pisang mas (Musa Acuminata (AA Group)) terhadap penurunan kadar glukosa darah mencit (Mus musculus) yang diinduksi aloksan

Sekitar 24 jam setelah penyuntikan aloksan dilakukan pemeriksaan kadar glukosa darah puasa kedua (GDP1) atau kadar glukosa darah pada hari ke 1 untuk mengecek kadar glukosa darah setelah induksi aloksan. Apabila mencit telah mengalami hiperglikemik selanjutnya pada masing-masing kelompok diberikan perlakuan akan diberikan perlakuaan dengan cara peroral sebagai berikut :

1. Tanpa Perlakuan (TP) : pemberian diet standar

2. Kontrol Negatif $(\mathrm{KN})$ : Pemberian Aloksan (Hari ke 0), Na CMC 1\% (Hari ke 1-10)

3. Kontrol Positif (KP) : Pemberian Aloksan (Hari ke 0) dan Metformin (Hari ke 1-10)

4. Perlakuan 1 (P1) : Pemberian Aloksan (Hari ke 0) dan Ekstrak etanol kulit Pisang Mas $1 \%$ (Hari ke 1 - 10)

5. Perlakuan 2 : Pemberian Aloksan (Hari ke 0) dan Ekstrak etanol kulit Pisang Mas 5\% (Hari ke 1 10)

6. Perlakuan 3 : Pemberian Aloksan $($ Hari ke 0) + Ekstrak etanol kulit Pisang Mas $25 \%$ (Hari ke 1 - 10)

Pengukuran kadar glukosa darah puasa pada sampel dilakukan pada hari ke 3 ke 7 dan ke 10 setelah pengukuran kadar glukosa darah setelah induksi aloksan (GDP1).

\section{Penentuan Kadar Glukosa Darah}

Sebelum pengambilan darah, terlebih dahulu alat glukometer diaktifkan, kemudian dimasukkan strip tes ke dalam alat glukometer. Darah mencit diambil pada bagian ekor dengan cara memotong sedikit ujung ekor mencit. Namun sebelumnya dibersihkan terlebih dahulu dengan kapas yang telah diberi alkohol $70 \%$. Darah diletakkan pada strip tes glukosa, kemudian ditunggu hingga kadar glukosa darah terbaca pada alat dengan durasi 10 detik dan hasilnya dapat dibaca pada monitor glukometer dalam satuan mg/dL. Kadar glukosa normal mencit berkisar 62-140 $\mathrm{mg} / \mathrm{dL}^{13}$ dan kadar glukosa darah mencit yang mengalami hiperglikemia melebihi angka $200 \mathrm{mg} / \mathrm{dl}^{14}$

\section{HASIL PENELITIAN}

\section{Determinasi}

Buah Pisang Mas yang digunakan dalam penelitian ini dilakukan determinasi di Laboratorium Bioteknologi Puslitbang Bioteknologi LP2M Pusat Kegiatan Penelitian Universitas Hasanuddin. Hasil dari determinasi menunjukkan bahwa buah pisang yang digunakan benar merupakan pisang jenis Musa acuminata (AA group) ${ }^{15}$ 
Uji aktivitas ekstrak etanol kulit pisang mas (Musa Acuminata (AA Group)) terhadap penurunan kadar glukosa darah mencit (Mus musculus) yang diinduksi aloksan

\section{Uji Fitokimia}

Tabel 1. Hasil Uji Fitokimia Ekstrak Etanol Kulit Pisang Mas

\begin{tabular}{|c|c|c|c|}
\hline Uji Kandungan & Hasil & Gambar & Keterangan \\
\hline Flavanoid & Positif $(+)$ & & $\begin{array}{c}\text { Terlihat lapisan } \\
\text { merah }\end{array}$ \\
\hline Saponin & Positif $(+)$ & & $\begin{array}{c}\text { Terbentuknya } \\
\text { Busa }\end{array}$ \\
\hline Tanin & Positif $(+)$ & & Kehitaman \\
\hline
\end{tabular}

Persentase penurunan kadar glukosa darah pada hewan uji dilakukan dengan membandingkan kadar glukosa darah hewan uji setelah induksi aloksan (GDP1) dengan kadar glukosa darah pada pemeriksaan setelah perlakuan. ${ }^{16}$

Tabel 2. Rata - Rata Kadar Glukosa Darah Hewan Uji

\begin{tabular}{cccccc}
\hline KELOMPOK & $\begin{array}{c}\text { GDP0 } \\
\text { (mg/dL) }\end{array}$ & $\begin{array}{c}\text { GDP1 } \\
\text { (mg/dL) }\end{array}$ & $\begin{array}{c}\text { GDP2 } \\
\text { (mg/dL) }\end{array}$ & $\begin{array}{c}\text { GDP3 } \\
\text { (mg/dL) }\end{array}$ & $\begin{array}{c}\text { GDP4 } \\
\text { (mg/dL) }\end{array}$ \\
\hline TP & 89,25 & 94,25 & 100,25 & 99,75 & 100,50 \\
KN & 83,75 & 430,25 & 570,25 & 491,0 & 472,50 \\
P1 & 87,25 & 432,75 & 578,25 & 345,5 & 246,0 \\
P2 & 87.0 & 425,25 & 537,25 & 267,75 & 193,0 \\
P3 & 82,75 & 429.50 & 469,25 & 165,25 & 113,5 \\
KP & 95,75 & 429,75 & 381,75 & 135,75 & 93,25 \\
\hline
\end{tabular}

Keterangan: TP (Tanpa Perlakuan);KN (Kontrol Negatif);KP (Kontrol Positif);P1 (Perlakuan 1 );P2 (Perlakuan 2); P3 (Perlakuan 3); GDP0 (Glukosa darah puasa awal); GDP1 (Glukosa darah puasa hari ke 1); GDP2 (Glukosa darah puasa hari ke 3); GDP3 (Glukosa darah puasa hari ke 7); GDP4 (Glukosa darah puasa hari ke 10). 
Uji aktivitas ekstrak etanol kulit pisang mas (Musa Acuminata (AA Group)) terhadap penurunan kadar glukosa darah mencit (Mus musculus) yang diinduksi aloksan

Tabel 3. Persentase Penurunan Kadar Glukosa Darah Pada Hewan Uji

\begin{tabular}{cccc}
\hline \multirow{2}{*}{ Kelompok } & \multicolumn{3}{c}{ Waktu (Hari) } \\
\cline { 2 - 4 } & Hari ke-3 & Hari ke-7 & Hari ke-10 \\
\hline KN & $32,53 \%(+)$ & $14,12 \%(+)$ & $9,82 \%(+)$ \\
P1 & $33,62 \%(+)$ & $20,16 \%(-)$ & $43,15 \%(-)$ \\
P2 & $26,33 \%(+)$ & $37,04 \%(-)$ & $54,61 \%(-)$ \\
P3 & $9,25 \%(+)$ & $61,52 \%(-)$ & $74,28 \%(-)$ \\
KP & $11,16 \%(-)$ & $68,41 \%(-)$ & $78,30 \%(-)$ \\
\hline
\end{tabular}

Keterangan : (-) persentase penurunan; (+) persentase kenaikan; KN (Kontrol Negatif); KP (Kontrol Positif); P1 (Perlakuan 1); P2 (Perlakuan 2); P3 (Perlakuan).

\section{PEMBAHASAN}

Penelitian ini menguji aktivitas ekstrak etanol kulit Pisang Mas terhadap penurunan kadar glukosa darah mencit (Mus musculus) yang diinduksi aloksan. Ekstrak etanol kulit Pisang Mas diperoleh dengan proses ekstraksi metode maserasi dengan bantuan sonikator (maserasi sonikasi) dengan menggunakan pelarut etanol $70 \%$. Pemilihan pelarut harus memenuhi beberapa pertimbangan yaitu murah dan mudah, stabil secara fisika dan kimia, bereaksi netral, tidak mudah menguap dan terbakar, bersifat selektif menarik zat berkhasiat yang dikehendaki, tidak mempengaruhi zat berkhasiat. ${ }^{17}$ Selain itu, pelarut didasarkan pada sifat kepolaran zat dalam pelarut saat ekstraksi. Senyawa polar hanya akan larut pada pelarut polar dan senyawa non polar juga hanya akan larut pada pelarut non polar. ${ }^{18}$ Etanol dipertimbangkan sebagai pelarut karena lebih selektif terhadap beberapa kapang dan kuman sulit tumbuh dalam etanol, tidak beracun, netral dan absorbsinya baik. Etanol $70 \%$ sangat efektif dalam menghasilkan jumlah bahan aktif yang optimal dimana bahan pengganggu hanya skala kecil yang turut ke dalam pelarut. ${ }^{19}$ Pemilihan metode ekstraksi disesuaikan dengan sifat kimia atau senyawa yang terkadung dalam bahan.Penggunakan sonikator dalam metode ekstraksi maserasi atau metode maserasi sonikasi dengan memanfaatkan gelombang ultrasonik bertujuan untuk mempersingkat pembuatan ekstrak. ${ }^{20}$ Beberapa keuntungan metode ekstraksi maserasi sonikasi yakni proses pembuatan ekstrak tergolong sederhana dan cepat serta kemungkinan rusaknya senyawa yang terkandung dalam suatu bahan dapat dihindari karena tidak menggunakan pemanasan sehingga cocok digunakan untuk senyawa yang tidak tahan panas. 
Uji aktivitas ekstrak etanol kulit pisang mas (Musa Acuminata (AA Group)) terhadap penurunan kadar glukosa darah mencit (Mus musculus) yang diinduksi aloksan

Penelitian ini menggunakan 24 ekor mencit jantan dengan berat ratarata 27 gram yang dibagi menjadi enam kelompok yaitu TP, KN, KP, P1, P2, dan P3. Pengukuran kadar glukosa darah dilakukan sebanyak 5 kali untuk masing - masing kelompok dengan menggunakan alat glukometer merk Nesco dan mencit dipuasakan terlebih dahulu selama 16 jam sebelum dilakukan pengukuran kadar glukosa darah puasa (GDP). Hal ini dilakukan agar tidak terjadi metabolisme glukosa dimana pada keadaan ini tubuh tidak mendapatkan asupan makanan sehingga mengakibatkan terpotongnya jalur asupan glukosa dari sistem pencernaan ke dalam darah. Terpotongnya jalur suplai glukosa dari sistem pencernaan berdampak langsung pada kadar glukosa darah.

Hasil pengukuran GDPO (Tabel 2) diperoleh rata-rata kadar glukosa darah mencit semua kelompok berada dalam kisaran normal dimana kadar glukosa normal mencit berkisar 62 $140 \mathrm{mg} / \mathrm{Dl} .{ }^{17}$ Setelah pengukuran GDP0, semua kelompok kecuali TP diberikan induksi aloksan.Tujuan pemberian aloksan adalah untuk menghasilkan keadaan hiperglikemia atau diabetes mellitus eksperimental pada hewan coba. Dosis aloksan yang digunakan pada penelitian ini yaitu $210 \mathrm{mg} / \mathrm{kgBB}$ yang merupakan hasil konversi dosis pada tikus putih yang disutikkan secara subkutan pada hewan uji. ${ }^{16}$ Degranulasi dan hilangnya sel $B$ pankreas sudah dapat terlihat pada 12-48 jam setelah induksi. ${ }^{28}$

Pengukuran kadar glukosa darah GDP1 dilakukan 24 jam setelah induksi aloksan. Hasil pengukuran GDP1 menunjukkan terjadinya peningkatan glukosa darah pada kelompok yang diinduksi aloksan (tabel 2). Kenaikan GDP yang signifikan pada hewan uji menunjukkan suatu keadaan hiperglikemia dimana apabila kadar glukosa darah melebihi angka 200 $\mathrm{mg} / \mathrm{dL}$ tersebut maka mencit dipastikan dalam keadaan hiperglikemik. ${ }^{21}$

Mekanisme hiperglikemia atau diabetes eksperimental yang ditimbulkan oleh aloksan terjadi dimana aloksan dalam darah berikatan dengan GLUT-2 (pengangkut glukosa) yang memfasilitasi masuknya aloksan ke dalam sitoplasma sel beta pankreas. Di dalam sel beta pankreas, aloksan menimbulkan depolarisasi berlebih pada mitokondria sebagai akibat pemasukan ion $\mathrm{Ca}^{2+}$ yang diikuti dengan penggunaan energi berlebih sehingga terjadi kekurangan 
Uji aktivitas ekstrak etanol kulit pisang mas (Musa Acuminata (AA Group)) terhadap penurunan kadar glukosa darah mencit (Mus musculus) yang diinduksi aloksan

energi dalam sel dan mengakibatkan

proses oksidasi terganggu. ${ }^{22}$

Mekanisme terjadinya diabetes melitus yang ditimbulkan aloksan juga melalui peningkatan Reactive Oxygen Species (ROS) melalui siklus reaksi yang hasil reduksinya berupa dialuric acid.Dialuric acid ini akan mengalami siklus redoks dan membentuk radikal superoksida. Kemudian radikal ini akan mengalami dismutase menjadi hydrogen peroksida dan pada tahap akhir mengalami katalisasi besi membentuk radikal hidroksil. Radikal hidroksil inilah yang menyebabkan kerusakan pada sel beta pankreas sehingga terjadi kondisi insulin dependen diabetes mellitus. Diabetes mellitus yang disebabkan oleh aloksan mengakibatkan keadaan diabetes dengan karakteristik yang serupa dengan diabetes tipe 1 pada manusia. $^{23}$

Setelah pemeriksaan GDP1, mencit diabetes diberi perlakuan estrak etanol kulit Pisang Mas dengan 3 konsentrasi bertingkat P1 (1\%), P2 (5\%), P3 (25\%) selama 10 hari secara peroral dan pemberian metformin dosis $140 \mathrm{mg} / \mathrm{kgBB}$ pada kelompok kontrol positif. Pemeriksaan kadar glukosa darah GDP2 dilakukan 3 hari setelah pemberian perlakuan. Hasil pemeriksaan GDP2, nilai rata-rata kadar glukosa darah beragam dari kelima kelompok perlakuan (Tabel 2). Rata-rata kadar glukosa darah kelompok KN, P1, P2, dan P3 mengalami kenaikan dari sebelumnya sedangkan KP mengalami sedikit penurunan. Selain itu, menunjukkan bahwa terjadi persentase kenaikan kadar glukosa darah pada kelompok P1 (33,62\%), P2 (26,33\%), dan P3 $(9,25 \%)$ (Tabel 3). Hal ini terjadi akibat masih terjadinya mekanisme kerusakan yang disebabkan oleh aloksan.Kerusakan pada sel beta terjadi pada 12 - 48 jam setelah induksi dan hasil peningkatan glukosa darah yang signifikan terlihat setelah empat hari setelahnya.Sedangkan pada kelompok KP mengalami penurunan dengan persentase sebesar $11,16 \% .{ }^{24}$

Pemeriksaan kadar glukosa darah selanjutnya (GDP3) dilakukan setelah pemberian perlakuan pemberian selama 7 hari. Pada GDP3 menunjukkan adanya penurunan kadar glukosa darah pada kelompok perlakuan. Persentase penurunan pada kelompok perlakuan (Tabel 3) konsentrasi $1 \%, 5 \%$ dan $25 \%$ sebesar $20,16 \%, 37,04 \%, 61,52 \%$ dan pada kelompok kontrol positif sebesar $68,41 \%$. Pengukuran kadar glukosa darah yang terakhir dilakukan setelah 
Uji aktivitas ekstrak etanol kulit pisang mas (Musa Acuminata (AA Group)) terhadap penurunan kadar glukosa darah mencit (Mus musculus) yang diinduksi aloksan

10 hari perlakuan (GDP4). Hasil pengukuran GDP4 (tabel 2) menunjukkan terjadi penurunan GDP yang lebih besar pada kelompok perlakuan. Dimana besar persentase penurunan untuk kelompok perlakuan konsentrasi $1 \%(43,15 \%)$, kelompok komsentrasi $5 \%(54,61 \%)$ dan pada kelompok konsentrasi $25 \%(74,28 \%)$. Persentase penurunan kadar glukosa darah pada kelompok konsentrasi $25 \%$ (P3) memiliki persen penurunan paling tinggi diantara konsentrasi lainnya yakni sebesar $74,28 \%$ mendekati penurunan kadar glukosa darah pada kelompok yang diberikan metformin dengan persentase penurunan sebesar $78,30 \%$.

Hasil pengukuran kadar glukosa darah dianalisis statistik menggunakan program SPSS 16,0 for windows dengan menggunakan analisis one way ANOVA. Syarat yang harus dipenuhi untuk melakukan uji ANOVA yaitu uji homogenitas dan uji normalitas. Hasil uji normalitas terhadap data hasil penelitian menunjukkan bahwa nilai signifikansi Kolmogrov Smirnov semua data memiliki nilai sig $>0,05$. Hal ini berarti semua kelompok yang dijadikan subjek dalam penelitian ini memiliki sebaran normal. Sementara itu, pada uji homogenitas varians menunjukkan nilai sig $>0,05$ menunjukkan adanya variasi yang homogen. Oleh karena itu syarat untuk dilakukan uji Anova telah terpenuhi. ${ }^{25}$

Berdasarkan hasil analisis statistik One Way Anova menunjukkan bahwa pemberian ekstrak etanol kulit Pisang Mas memiliki pengaruh yang nyata terhadap penurunan kadar glukosa darah $(p<0,05)$. Setelah itu dilanjutkan dengan uji LSD untuk melihat perbedaan antar kelompok uji. Uji LSD pada GDP2, menunjukkan kontrol negatif berbeda secara bermakna dengan kelompok kontrol positif dan kelompok perlakuan konsentrasi $5 \%$ dan $25 \%$ tetapi tidak berbeda secara bermakna dengan kelompok konsentrasi $1 \%$. Pada uji LSD GDP3 dan GDP4 terdapat perbedaan yang bermakna antara kelompok $\mathrm{KN}$ dengan kelompok perlakuan lainnya. Hal ini karena kontrol positif dan kelompok uji konsentrasi $1 \%$, $5 \%$, dan $25 \%$ telah mengalami penurunan kadar glukosa darah sedangkan kontrol negatif tidak mengalami penurunan kadar glukosa darah.

Analisis LSD pada hari ke 3,7 dan 10 kelompok uji menunjukkan perbedaan yang bermakna satu dengan yang lainnya. Hal ini menunjukkan bahwa kelompok uji 
Uji aktivitas ekstrak etanol kulit pisang mas (Musa Acuminata (AA Group)) terhadap penurunan kadar glukosa darah mencit (Mus musculus) yang diinduksi aloksan

konsentrasi $1 \%$, $5 \%$ dan $25 \%$ memiliki efek yang berbeda dalam menurunkan kadar glukosa darah. Nilai glukosa darah pada kelompok perlakuan konsentrasi $25 \%$ dan kelompok kontrol positif (metformin) pada hari ke 10 tidak menunjukkan perbedaan yang nyata. Hal ini diinterpretasikan ekstrak etanol Kulit Pisang Mas memberikan efek yang hampir sama dengan kontrol positif. Penurunan kadar glukosa darah pada kelompok P1, P2, dan P3 dikarenakan kandungan senyawa yang terdapat dalam ekstrak etanol kulit pisang yang memiliki efek antihiperglikemik. ${ }^{16} \quad$ Untuk membuktikan kandungan senyawa yang dimaksud terdapat dalam sampel dilakukan dengan uji fitokimia. Berdasarkan hasil uji fitokimia terhadap ekstrak etanol kulit Pisang Mas diperoleh hasil bahwa golongan senyawa yang terkandung pada ekstrak etanol kulit Pisang Mas yaitu senyawa flavonoid, saponin dan tanin.

Flavanoid merupakan senyawa fenol yang dimiliki oleh banyak tanaman. Flavanoid di dalam tubuh berfungsi sebagai antioksidan sehingga memiliki peran sangat baik untuk melindungi struktur sel meningkatkan efektivitas vitamin C, sebagai antiinflamasi dan sebagai antibiotic. $^{31}$ Mekanisme sebagai antioksidan dengan menghambat reaksi oksidasi atau suatu senyawa yang dapat menetralkan radikal bebas yang dapat melindungi jaringan dari kerusakan akibat radikal bebas dengan melengkapi kekurangan elektron yang dimiliki oleh radikal bebas yang dapat menimbulkan stress oksidatif. ${ }^{26}$ Antioksidan flavonoid memiliki kemampuan untuk menurunkan stress oksidatif dan mengurangi adanya ROS. Hal ini bersifat protektif terhadap sel $B$ sebagai penghasil insulin dan meningatkan sensitivitas insulin. ${ }^{33}$ Senyawa flavanoid sebagai agen antihiperglikemik yang potensial karena flavonoid berfungsi sebagai inhibitor glukosidase. Glukosidase inhibitor merupakan agen potensial untuk terapi DM karena glukosidase mempengaruhi proses biologis secara relevan. Enzim glukosidasi berlokasi di brush order intestinal di dalam usus halus yang merupakan tempat absorbsi glukosa dan fruktosa. Enzim glukosidasi dibutuhkan untuk pemecahan karbohidrat sebelum diserap sebagai monosakarida. Penghambatan enzim alfa glukosidase ini menyebabkan penundaan penyerapan glukosa yang pada akhirnya juga akan menurunkan kadar glukosa darah. ${ }^{27}$ Selain itu, flavonoid 
Uji aktivitas ekstrak etanol kulit pisang mas (Musa Acuminata (AA Group)) terhadap penurunan kadar glukosa darah mencit (Mus musculus) yang diinduksi aloksan

memiliki mekanisme dalam penghambatan

fosfodieterase

sehingga kadar CAMP dalam sel beta pankreas meningkat. ${ }^{28} \mathrm{Hal}$ ini akan menstimulasi pengeluaran protein kinase A (PKA). Peningkatan kadar cAMP akan menyebabkan terjadinya penutupan pada kanal $\mathrm{K}^{+}$ATP dalam membran plasma sel beta. Keadaan ini akan mengakibatkan terjadinya depolarisasi membran dan membukanya saluran $\mathrm{Ca}$ sehingga mempercepat masuknya ion $\mathrm{Ca}$ ke dalam sel. Peningkatan ion $\mathrm{Ca}$ dalam sitoplasma sel beta akan menyebabkan peningakatan sekresi insulin oleh sel beta pancreas. ${ }^{29}$

Saponin merupakan senyawa kimia yang banyak terdapat pada tanaman. Saponin dimetabolisme di dalam tubuh oleh mikroflora yang berada di usus halus dan metabolitnya akan di absorbsi lewat gastrointestinal kemudian bekerja secara sistemik. Saponin berfungsi sebagai antihiperglikemik adalah triterpene saponin dengan mekanisme kerja yakni mencegah pengosongan lambung dan mencegah peningkatan uptake glukosa pada brush order membran intestinal. Selain itu saponin juga bekerja untuk mencegah penyerapan glukosa dengan cara mencegah transpor glukosa menuju brush order intestinal di usus halus yang merupakan tempat penyerapan glukosa sehingga mengakibatkan penurunan kadar glukosa darah. ${ }^{30}$

Tanin menurunkan absorbsi nutrisi dan mengahmbat penyerapan glukosa di intestinal, selain itu menginduksi regenerasi sel beta pankreas yang berefek pada sel adiposa sehingga menguatkan aktivitas insulin. Tanin dapat memperbaiki stress oksidatif patologik pada keadaan diabetik, serta bertindak sebagai anti radikal bebas dan mengaktifkan enzim antioksidan yang meregenerasi sel beta pancreas. ${ }^{38}$ Mekanisme proanthocyanidins dalam menurunkan glukosa darah dengan menekan stress oksidatif. Penekanan stress oksidatif tersebut melalui penghambatan peroksidasi lipid, dan generasi ROS. ${ }^{31}$

Pemberian ekstrak etanol kulit Pisang Mas memiliki pengaruh yang nyata terhadap penurunan kadar glukosa darah. Pada penelitian ini menunjukkan konsentrasi ekstrak etanol kulit Pisang Mas yang paling efektif pada konsentrasi tertinggi yaitu konsentrasi $25 \%$ telah mampu menurunkan kadar glukosa darah dengan persentase $74,28 \%$ mendekati presentase penurunan pada kelompok kontrol positif metformin dosis 
Uji aktivitas ekstrak etanol kulit pisang mas (Musa Acuminata (AA Group)) terhadap penurunan kadar glukosa darah mencit (Mus musculus) yang diinduksi aloksan

$140 \mathrm{mg} / \mathrm{kgBB}$ yaitu sebesar $78,30 \%$ dan keduanya tidak berbeda signifikan dengan kelompok kontrol normal. Suatu dosis yang memiliki efek mendekati normal menunjukkan bahwa senyawa aktif yang terkandung di dalamnya terkonsentrasi efektif optimum, sedangkan pada dosis lain masih kurang sehingga mempunyai efek yang kurang efektif dan tidak memadai sehingga efek antihiperglikemik yang muncul lebih kecil. ${ }^{32}$ Metformin dipilih sebagai kontrol positif sebab mekanisme kerja dari metformin melalui peningkatan penggunaan glukosa oleh sel otot dan adiposa, penurunan produksi glukosa di hepar, penurunan sensitifitas reseptor insulin dan penurunan absorbsi glukosa di usus ${ }^{[3]}$. Mekanisme ini menyerupai mekanisme dari senyawa flavonoid, saponin dan tanin yang terdapat pada kulit Pisang Mas dalam menurunkan kadar glukosa darah.

Induksi dosis tunggal aloksan dapat menyebabkan keadaan diabetes dapat bersifat reversibe[ [34].Pada data terlihat sedikit terjadi penurunan kadar glukosa darah pada kontrol negatif karena didukung regenerasi sel $B$ pankreas yang sebenarnya induksi aloksan tidak seluruhnya merusak sel B pankreas sehingga masih terdapat insulin yang masih bisa dieksresi ${ }^{354]}$. Meskipun terjadi sedikit penurunan namun kadar glukosa darah pada hewan uji masih dikatakan diabetes. Faktor lain yang dapat mempengaruhi yakni dosis induksi aloksan. Aloksan pada dosis dibawah $140 \mathrm{mg} / \mathrm{kgBB}$ menginduksi diabetes dan mampu mengembalikan kadar glukosa darah normal tikus dalam waktu 1 minggu. Aloksan dosis diatas 160 $\mathrm{mg} / \mathrm{kgBB}$ dapat menyebabkan kondisi diabetes yang stabil dan mampu bertahan selama 1 bulan. Sedangkan pada aloksan dosis 180 $\mathrm{mg} / \mathrm{kgBB}$ menunjukkan kondisi diabetes yang berat, angka kematian yang tinggi, dan kerusakan ginjal. ${ }^{36}$ Pada penelitian ini digunakan aloksan dosis $150 \mathrm{mg} / \mathrm{kgBB}$ yang diinduksikan secara subkutan. Pengamatan kelompok TP yang merupakan kontrol hewan sehat menunjukkan variasi kadar glukosa darah pada kelima kali pemeriksaan. Hal ini dapat terjadi disebabkan dari faktor biologis dari mencit yang meliputi jumlah dan kualitas reseptor insulin, serta kondisi pankreas. Selain itu, stres yang dialami oleh mencit akibat pengambilan darah merupakan faktor pengganggu yang dapat mengakibatkan variasi dalam pengukuran kadar glukosa darah. ${ }^{37}$ 
Uji aktivitas ekstrak etanol kulit pisang mas (Musa Acuminata (AA Group)) terhadap penurunan kadar glukosa darah mencit (Mus musculus) yang diinduksi aloksan

KESIMPULAN

Berdasarkan hasil penelitian yang telah dilakukan maka pemberian ekstrak etanol kulit Pisang Mas (Musa acuminata (AA group)) konsentrasi $1 \%$, $5 \%$, dan $25 \%$ selama 10 hari memberikan pengaruh nyata terhadap penurunan kadar glukosa darah pada mencit (Mus musculus) yang diinduksi aloksan $(p<0,05)$ dan konsentrasi 25\% tidak berbeda signifikan dengan metformin dosis $14 \mathrm{mg} / \mathrm{kgBB}(\mathrm{p}>0,05)$.

\section{DAFTAR PUSTAKA}

1. Murray RK, Granner DK, Rodwell VW. Biokimia harper (27 ed.) Jakarta : Penerbit Buku Kedokteran EGC, 2009.

2. Chaiyasut C, Kusirisin W, Lailerd $N$, Lertrakarnoon $P$, Suttajit $M$, Srichairatanakool S. Effect of Phenolic Compounds of Fermented Thai Indigenous Plants on Oxidative Stress in StrepzotosinInduced Diabetic Rats. Research Article.2011;15(2):118123.

3. Bruyette D. Diabetes Mellitus [internet] 2016. [Diakses pada 4 Desember 2017]. Tersedia di : http://www.merckvetmanual.com/e ndocrine-system/the-

pancreas/diabetes-mellitus

4. American Veterinary Medical Association. Diabetic Pets. USA [internet]. 2010. [Diakses pada 13 Oktober 2017] Tersedia di :https://www.avma.org/public/PetC are/Pages/Diabetes-inPets.aspx.

5. Jamaluddin AW, Muslimin LW, Djide MN. Ekstrak Daun Jambu Biji (Psidium guajava L) sebagai inhibitor pertumbuhan bakteri zoonosis proteus mirabilis yang diisolasi dari daging ayam broiler. Jurnal As-Syifaa.2018;10(01):3036.

6. Someya S, Yoshiki Y, Okubo K. Antioxidant Compounds From Banana (Musa cavendish). Journal Food Chemistry.2002;79(3):351-4.

7. Kanazawa K, Saksakibara H. High Content of Dopamine, A Strong Antioxidant in Cavendish Banana.J Agric Food Chem. 2000;25(3):84448.

8. Sighal M, Ratra P. Antioxidant Activity, Total Flavonoid and Total Phenolic Content of Musa acuminata Peel Exctracts.Global J. Pharmacol.2013;7(2):188-22.

9. Satriany P. Pengaruh Pemberian Ekstrak Herba Daun Sendok (Plantago major L.) Terhadap Kadar Glukosa Darah Mencit Balb/c Induksi Streptozotocin (Skripsi). Surakarta: Universitas Sebelas Maret,2010.

10. Departemen Kesehatan RI. Acuan Sediaan Herbal. Direktorat Pengawas Obat dan Makanan. Jakarta: Departemen Kesehatan Republik Indonesia,2000.

11. Harborne JB. Metode Fitokimia : Penuntun Cara Modern Menganalisis Tumbuhan, terjemahan Kosasih Padmawinata dan Iwang Soediro. Bandung: Institut Teknologi Bandung,1987.

12. Kusumawati D. Bersahabat Dengan Hewan Coba. Yogyakarta: Gadjah Mada University Press,2004. 
Uji aktivitas ekstrak etanol kulit pisang mas (Musa Acuminata (AA Group)) terhadap penurunan kadar glukosa darah mencit (Mus musculus) yang diinduksi aloksan

13. Pasaribu R, Hutahaean S, llyas S. Uji Antihiperglikemika Ekstrak Etanol Daun Kembang Bulan (Tithonia diversifolia) pada Mencit (Mus musculus) yang diinduksi Diabetes Dengan Aloksan. J Biosains,2015;1(2)2460-6804.

14. Suharmiati. Pengujian Bioaktivitas Anti Diabetes Mellitus Tumbuhan Obat.Badan Penelitian dan Pengembangan Pelayanan dan Teknologi Kesehatan. Surabaya: Departemen Kesehatan Republik Indonesia,2003.

15. Adams, Kathrynn A, Lawrence, Eva K. Research Methods Statistics, and Applications. California: Sage Publications Inc.,2015.

16. Gembong T. Morfologi Tumbuhan. Yogyakarta: Gadjah Mada University Press,2007.

17. Rosdiana, Nurul F. Uji Efek Antihiperglikemik Ekstrak Etil Asetat Lumut Hati (Mastigophora diclados) Dengan Metode Induksi Aloksan (Skripsi). Jakarta: Universitas Islam Negeri Syarif Hidayatullah,2013.

18. Syamsuni HA. Ilmu Resep. Jakarta: Penerbit Buku Kedokteran EGC,2006.

19. Gritter RJ, Bobbit JM, A. E. Schwarting. Bandung: Pengantar Kromatografi. Institut Teknologi Bandung, 1991.

20. Ashley C, et al. Pro-Poor Tourism Strategies: Making Tourism Work for the Poor, A Review of Experience [internet] 2001. [Diakses pada 9 Februari 2017]. Tersedia di http://www.propoortourism.org.uk/p pt report.pdf.
21. Lenzen S. The Mechanism of Alloxan and Streptozotocin Induced Diabetes. Diabetologia 2008 51:216-226 DOI 10.1007/s00125007-0886-7

22. Szkudelski T. The Mechanishm of Alloxan and streotozotocin Action in $\beta$ Cells of the Rat pankreas. Physiology research.2001;50:53654.

23. Robinson T. Kandungan Organik Tumbuhan Tinggi. Edisi ke 4. Terjemahan Koasasih Padmawinata. Bandung: ITB Press, 1995.

24. Prakash A. Antioksidant Activity. Journal Medallions Laboratories. 2000;19(2):1-4.

25. Aprilia, Fitri I, Salim MN, Daud R, Armansyah T, Asmila N, Jamin F. Pengaruh pemberian Kacang Pnajang (Vigna unguiculata) Terhadap Kadar Glukosa Darah Mencit (Mus musculus) yang Diinduksi Aloksan. J Medika Veterinaria. 2015;9(2):0853-1943.

26. Kaneto et al. Benefical effect of Antioxidants in Diabetic Possible Protection of Pancreatic B-Cells Against Glucose Toxicity[internet] 1999. [Diakses pada 15 Agustus 2017]. Tersedia di http://diabetes.diabetesjournals.org lcgi/reprint/48/12/2398.pdf.[online].

27. Winarsi H. Isoflavon : Berbagai Sumber, Sifat, Dan Manfaatnya pada penyakit Degenerative. Yogyakarta: Gadjah Mada university Press,2006.

28. Puspati NKS. Anthara MS., Dharmayudha AAGO. Pertambahan Bobot Bada Tikus Diabetes Dengan Pemberian 
Uji aktivitas ekstrak etanol kulit pisang mas (Musa Acuminata (AA Group)) terhadap penurunan kadar glukosa darah mencit (Mus musculus) yang diinduksi aloksan

Ekstrak Etanol Buah Naga Daging Putih. Journal Indoneisa Medicus Veterinus.2013;2(2):224-34.

29. Harapan, Jamil KF, Hayati Z, Muhammad I. Peran Puasa Dalam Remodelling Sel Enteroendokrin Untuk Mencegah Diabetes Mellitus Tipe 2. JIMKI.2010;1(1): 36-40.

30. Rao A. Gurfinkel. The Bioactivity of Saponins Triterpenoid and Steroidal Glycosides. Drugs Metab Grug Interact.2000 211-35.

31. Kumari M, Jain S. Tannins : An Antinutrient with Positive Effect to Manage Diabetes. Research Journal of Recent Science.2012;1(12) : 70 -1.

32. Yokuzawa $\mathrm{T}$, Cho EJ, Park $\mathrm{CH}$, Kim HJ. Rivies Article Protective Effect of Proanthocyanidin Agaisnst Diabetic Oxidative Stress.EvidenceBased Complementary and Alternative Medicine.2012;22:204
33. Fidrianny I, Padmawinata K, Soetarno S, Yulinah E. Efek Antihipertensi dan Hipotensi beberapa Fraksi dari Ekstrak Etanol Umbi Lapis Kucai (Allium schoenoprasum L., Lliliaceae). Jurnal Matematika dan Sains.2003; 8(4):147-150.

34. Widowati W. Potensi Antioksidan sebagai Antidiabetes. JKM.2008; 7(2):1-10.

35. Dor. Adult Pancreatic $B$ are Performed by Cell Duplication Rather than Stem Cell Differentiation. Nature.2005:429.

36. Chougale AD, Shirmant NP, Pradeep MG, Akalpita UA. Optimization of Alloxan Dose in Essential to Induce Stable Diabetes for Prolonged Period. Assian Journal of Biochemistry. 2007;2(6):402-408.

37. Doughari JH. Antimicrobial Activity of Tamarindus indica Linn. Tropical Journal of Pharmaceutical Research. 2006;5(2):597-60. 